\title{
PRODUCTION AND COMPARATIVE QUALITY EVALUATION OF CHIN-CHIN SNACKS FROM MAIZE, SOYBEAN AND ORANGE FLESHED SWEET POTATO FLOUR BLENDS.
}

\author{
*Ndife, J., Abasiekong, K. S., Nweke, B., Linus-Chibuezeh, A., Ezeocha, V. C.
}

Department of Food Science and Technology, Michael Okpara University of Agriculture,Umudike, Abia State, Nigeria.

*Corresponding Authors' Email: Jothel2000@ gmail.com

\begin{abstract}
Most snacks are prepared from basically cereal flours which are nutritionally inadequate. There is the need to complement the nutrient content of these snacks by varying the food sources. Chin-chin snacks were produced from composite flours of Maize, soybean and OFSP with the following formation; sample A (50\%: $25 \%$ : 25\%), B (25\%: 25\%: 50\%), C (25\%: 50\%: 25\%), D (0\%: 50\%: 50\%) and E (50\%: 50\%: $0 \%)$. Wheat flour $(100 \%)$ served as the control $\mathrm{F}$. The flour bends were analysed for functional properties while the chin-chin snacks were analysed for their nutrient and sensory qualities. The result of functional properties of the flours showed that bulk density of wheat flour $(\mathrm{F})$ was the highest $(0.746 \mathrm{~g} / \mathrm{ml})$. OFSP flour enhanced the water absorption capacity of the flour blends. Flour blends with soybean recorded higher values in foam capacity $(11.20-22.55 \%)$. In proximate composition, the moisture was low (3.80 $-4.80 \%)$ in the chin-chin. Higher fibre content $(2.60-4.20 \%)$ was obtained in samples containing higher proportion (50\%) of OFSP. Samples D (19.38\%) and C (18.80\%) with higher soybean, recorded higher protein values. The mineral and the vitamin contents of snacks from composite flours were higher than that of the control F. Vitamin $\mathrm{B}_{1}, \mathrm{~B}_{2}, \mathrm{~B}_{3}$ and $\beta$-carotene contents of the snacks were enhanced by OFSP. The sensory evaluation showed preference for snack F (100\% wheat flour) followed by snack A (50\% maize, $25 \%$ soybean and $25 \%$ OFSP). However, improved nutrient dense chin-chin snacks were produced from the composite flours.
\end{abstract}

Keywords: Proximate, Antinutrients, Phytochemicals, Composite, Sensory

\section{INTRODUCTION}

Snack foods have been part of human diet for a long time and have contributed tremendously to economy of every nation (Lasekan and Akintola, 2002). The demand for snacks is attributed to the rapid population and urbanization of both developed and developing countries (Ugwuanyi et al., 2020). Snacks contribute an important part of many consumers' daily nutrient and caloric intake (Awoyale et al., 2011). The most widely consumed snacks are cereal based products, which generally are low in nutrient density. They are generally regarded as convenience food and have been part of the human diet for a long time (Lasekan and Akintola, 2002). Snacks foods are cheap, easy to eat and readily available on the streets, shops, schools, among others (Ugwuanyi et al., 2020). Chin-chin is a fried snack popular in West African countries especially Nigeria. It is a sweet, hard, fried or baked product made of wheat flour dough and other ingredients (Akubor, 2004; Mepba et al., 2007).

Legumes are the edible seeds of leguminous plants belonging to the family Leguminosae. They are known to contain doubled amount of protein compared to cereals and this is usually added to the cereal based snacks to improve their protein content (Enwere, 1998; Fasogbon et al., 2017). Legumes has been successfully used in baked products to obtain protein-enriched products with improved amino acid balance (Mohammed et al., 2012). Soybean (Glycine max) is a rich source of protein, fat, carbohydrate, vitamins, minerals, and water. It is regarded as poor man's meat in the developing countries where animal products are costly. It is a right substitute to mitigate the challenge of protein energy malnutrition (Enwere, 1998; Fasoyiro et al., 2006).

Orange-fleshed sweet potato (OFSP) is one of the sweet potato varieties being promoted in sub-Saharan Africa as a food-based measure to complement other efforts in reducing the occurrence of vitamin A deficiency (Hotz et al., 2012; Tumwegamire et al., 2004). In spite of its high nutritional value, OFSP is underutilized in Nigeria compared with other root and tuber crops consumed (Baafi et al., 2015). OFSP has been found to be a good composite to wheat flour if pureed for snacks. It is grown in many tropical and subtropical regions. Among the world's major food crops, seet potato produces the highest amount of edible energy per hectare per day (Singh et al., 2008). Among the root and tuber crops, sweet potato is the only one that has a positive per capita annual rate of increase in production in sub-Saharan Africa (Tumwegamire et al., 2004).

The concept of composite flour technology initiated by the Food and Agriculture Organization (FAO) in 1964 was to support developing countries by encouraging the use of indigenous crops such soybean, maize and others in partial substitution of wheat flour (Wan and Kinsella, 1991; Enwere, 1998), and reduce over dependency on wheat flour as the sole cereal for pastries and confectioneries. Composite flour is considered advantageous in developing countries as it reduces 
the importation of wheat flour and encourages the use of locally grown crops as flour (Singh et al., 2008). Thus, several developing countries have encouraged the initiation of programs to evaluate the feasibility of alternative locally available flours as a substitute for wheat flour. The objectives of this work therefore, was to produce chin-chin snacks from the flour blends of maize, soybean and orange flesh sweet potatoes (OFSP), evaluate and compare its quality composition with conventional chin-chin from wheat flour.

\section{MATERIALS AND METHODS}

\section{Source of materials}

Raw materials for this research (maize grains, soybean seeds, wheat flour, butter, egg, sugar, nutmeg, baking powder, vanilla oil, powdered milk, salt and vegetable oil) were purchased at Umuahia main market (Ubani), Abia state, while orange fleshed sweet potatoes (OFSP) was obtained from National Root Crop Research Institute (NRCI) Umudike, Abia State, Nigeria.

\section{Preparation of flours}

OFSP: was produced using the method of Bibiana et al. (2014). OFSP tubers were washed, peeled and grated. The grated OFSP was spread out on trays and oven dried at $60{ }^{\circ} \mathrm{C}$ for 24 hours. The dried OFSP was milled using a hammer mill
(9FC-360A JinJuhong machinery, China), sieved through a $500 \mu \mathrm{m}$ mesh and stored in air tight containers in a cold room at $4{ }^{\circ} \mathrm{C}$ prior to use.

Soybean flour: The method of Okoye et al. (2008) was adopted; the soybean seeds were cleaned, sorted to remove pests, insects and other contaminants. Thereafter, it was soaked for $6 \mathrm{~h}$ to remove anti-nutrients inherent in soybean and then dehulled and dried in an air oven (Kappa Catering Equipment, Italy) at $60{ }^{\circ} \mathrm{C}$. This was followed by toasting at $120{ }^{\circ} \mathrm{C}$ for 10 minutes, it was then milled and allowed to pass through 500 um mesh size to obtain fine flour, the flour was stored at $4{ }^{\circ} \mathrm{C}$ prior to time of use.

Preparation of maize flour: Maize flour was produced according to the method of Awoyale et al. (2011). The maize grains were sorted by hand to remove stones, chaff, and damaged grains. The cleaned maize was washed with distilled water, dried in an oven at $60{ }^{\circ} \mathrm{C}$ for $4 \mathrm{~h}$ and milled in an attrition mill and sieved with a 500 um mesh.

\section{Formulation of composite flours}

The flour composition ratio for chin-chin production is presented in Table 1.

Flours from maize, soybean and orange flesh potatoes (OFP) were blended to up one hundred gram flour for the chin-chin production, while chin-chin from $100 \%$ wheat flour served control.

Table 1: Composite flour formulation (\%)

\begin{tabular}{lllllll}
\hline Flour & A & B & C & D & E & F \\
\hline Maize & & & & 0 & 50 & 0 \\
Soybean & 50 & 25 & 25 & 50 & 50 & 0 \\
OFSP & 25 & 25 & 50 & 50 & 0 & 0 \\
Wheat & 25 & 50 & 25 & 0 & 0 & 100 \\
Total: & 0 & 0 & 0 & 100 & 100 & 100 \\
\hline
\end{tabular}

\section{Production of chin-chin}

Each composite flours (100 g) was put in a bowl followed by the addition of $2 \mathrm{~g}$ of salt and $0.5 \mathrm{~g}$ of ground nutmeg respectively. $25 \mathrm{~g}$ of sugar, $10 \mathrm{~g}$ of powdered milk, $1 \mathrm{~g}$ of baking powder, were manually mixed with $25 \mathrm{~g}$ of margarine to form a batter. The batter was then mixed with flours and 20 $\mathrm{ml}$ of water was added to the mixture, which was thoroughly kneaded to make fairly stiff dough. The dough was rolled tightly to $1 \mathrm{~cm}$ thickness on a board and cut into uniform cubes and were fried in deep hot vegetable oil at $180{ }^{\circ} \mathrm{C}$ for $8 \mathrm{~min}$ until golden brown was observed. The chin-chin was drained off oil, cooled and packaged in an air tight container for analysis.

\section{METHODS OF ANALYSIS}

\section{Proximate analysis}

The determination of the chemical composition of the samples for moisture, ash, protein, fat, and fiber contents were determined by methods described by AOAC (2010). Carbohydrate content was determined by difference using the Atwater factors

Mineral analysis

Each sample was digested by the wet ashing method prior to mineral content determination using atomic absorption spectrophotometer for $\mathrm{Ca}, \mathrm{Mg}$ and $\mathrm{Fe}$ and Corning 400 flame photometer for $\mathrm{K}$ and $\mathrm{Na}$ (AOAC, 2005). The Phosphorus content was determined colorimetrically with Jenway 6100 spectrophotometer using the method described by Nielsen (2003).

\section{Vitamin analysis}

The spectrophotometric method described by Jacobs, (1999).was used; the absorbance of the sample and the standard solutions were measured with a UVSpectrophotometer at their respective wavelengths. The concentrations of the vitamins in the prepared samples were run against known standards calibrated curve.

\section{Functional properties analysis}

The bulk density, water and oil absorption capacities, foaming capacity and of the flour samples were evaluated according to the method of Onwuka (2018).

\section{Phytochemical analysis}

The AlCl3 method of Harborne (1993) was used for the determination of the total flavonoid content. The tannin content was determined using the Follin-Dennis spectrophotometric method as described by Pearson (1976). The spectrophotometric and titration methods described by 
Onwuka (2005) were used to determine the phytate, oxalate and hydrogen

\section{Sensory analysis}

Sensory evaluation of the chin-chin was carried out using a 9point Hedonic scale as described by (Iwe, 2010). 20 semitrained panellists from the department of Food Science and Technology, Michael Okpara University of Agriculture, Umudike were used. The 9-point Hedonic scale ranged from extremely like (9) to extremely dislike (1), while 5 is neither like or dislike Each sample was evaluated for flavour, colour, taste, texture and overall acceptability.

\section{Statistical analysis}

Data are presented as mean \pm standard deviations. The results obtained were subjected to Analysis of Variance (ANOVA) using Statistical package for social sciences (SPSS version 20). Means were separated using Duncan's multiple Range Test (DMRT). Significant difference was determined at P < 0.05 .

\section{RESULTS AND DISCUSSION}

\section{Functional properties of flour blends}

Functional properties of flour blends are presented in Table 2. Bulk density of the flour samples ranged from 0.667- 0.746 $\mathrm{g} / \mathrm{ml}$. Bulk density of wheat flour $(\mathrm{F})$ was higher $(0.746 \mathrm{~g} / \mathrm{ml})$ than recorded for composite flours $(0.667-0.728 \mathrm{~g} / \mathrm{ml})$. There was significant difference $(\mathrm{p}<0.05)$ in bulk density of the flour blends. Omoniyi et al. (2016) reported higher bulk density value for sweet potato and soybean composite flour. The high bulk density value recorded for the flour blends might likely aid its industrial applications, and also its application in bakery industry. High bulk density of a material is also important in relation to handling requirements and packaging (Linus-Chibuezeh et al., 2017).
The water absorption capacity (OAC) of the flour blends ranged from $1.20 \mathrm{~g} / \mathrm{ml}$ (sample F) to $2.60 \mathrm{~g} / \mathrm{ml}$ (sample B). There was significant difference $(\mathrm{p}<0.05)$ in OAC of the flour blends. The result showed that OFSP flour enhanced the water absorption capacity of the flour blends. Similar observation was reported by Omoniyi et al. (2016) for sweet potato and Bambara nut flour blends. Also, Wan and Kinsella (1991) had earlier reported that the ability of food materials to absorb water is sometimes attributed to the starch content. This suggests that increase in water absorption in the blends can be useful in bakery products such as bread, cakes, cookies that requires hydration to improve dough handling characteristics. The oil absorption capacity (OAC) of the flour blends ranged from $1.35-2.20 \mathrm{~g} / \mathrm{ml}$. Sample B recorded highest value in OAC, while control sample (100\% wheat flour) had the least. The result showed that OFSP flour increased the OAC of the flour blends. Similar relationship had been suggested by Oyeyinka et al. (2014). Wan and Kinsella (1991) also attributed the mechanism of oil absorption to interaction between fat and non-polar chain of protein as well as the physical entrapment of oil. This affirms the reason for the higher value obtained with increase in wheat flour in the blends. Oil absorption capacity is important as it could influence the acceptability and storage stability of food products.

The foam capacity of the flour blends ranged from $10.55 \%$ (sample B) to $22.55 \%$ (sample C). Flour from $25 \%$ maize, $50 \%$ soybean and $25 \%$ OFSP recorded highest value in foam capacity $(22.55 \%)$. There was significant difference $(p<0.05)$ in foam capacity of the composite flours. The blends containing higher proportion of soybean showed higher foam capacity values $(16.23-22.55 \%)$. This is not surprising as legumes have been reported to have high foam capacity due to their high protein content (Omoniyi et al., 2016).

Table 2: Functional Properties of the Composite Flours.

\begin{tabular}{lllll}
\hline Samples & Bulk density $(\mathrm{g} / \mathrm{ml})$ & WAC $(\mathrm{g} / \mathrm{ml})$ & OAC $(\mathrm{g} / \mathrm{ml})$ & Foam capacity (\%) \\
\hline A & $0.676^{\mathrm{e}} \pm 0.03$ & $2.40^{\mathrm{b}} \pm 0.14$ & $1.80^{\mathrm{b}} \pm 0.14$ & $18.43^{\mathrm{c}} \pm 0.25$ \\
B & $0.667^{\mathrm{f}} \pm 0.00$ & $2.60^{\mathrm{a}} \pm 0.00$ & $2.20^{\mathrm{a}} \pm 1.14$ & $11.20^{\mathrm{e}} \pm 0.07$ \\
C & $0.728^{\mathrm{b}} \pm 0.00$ & $2.00^{\mathrm{c}} \pm 0.00$ & $1.45^{\mathrm{cd}} \pm 0.07$ & $22.55^{\mathrm{a}} \pm 0.07$ \\
D & $0.688^{\mathrm{d}} \pm 0.02$ & $2.30^{\mathrm{b}} \pm 0.14$ & $1.60^{\mathrm{bc}} \pm 0.00$ & $16.23^{\mathrm{d}} \pm .13$ \\
E & $0.714^{\mathrm{c}} \pm 0.3$ & $2.20^{\mathrm{b}} \pm 0.00$ & $1.55^{\mathrm{cd}} \pm 0.07$ & $20.24^{\mathrm{b}} \pm 0.10$ \\
F & $0.746^{\mathrm{a}} \pm 0.06$ & $1.20^{\mathrm{d}} \pm 0.00$ & $1.35^{\mathrm{d}} \pm 0.07$ & $10.55^{\mathrm{f}} \pm 0.00$
\end{tabular}

Values are mean \pm SD. Values on the same column with different superscript are significantly different $(\mathrm{p}<0.05)$

Sample: A- Maize 50\%: Soybean 25\%: OFSP 25\%; B- Maize 25\%: Soybean 25\%: OFSP 50\%; C- Maize 25\%: Soybean 50\%: OFSP 25\%; D- Maize 0\%: Soybean 50\%: OFSP 50\%; E- Maize 50\%: Soybean 50\%: OFSP 0\%

F- $100 \%$ wheat

\section{Proximate composition of chin-chin snacks}

The proximate composition of chin-chin snacks is shown in Table 3.

The moisture content of the chin-chin ranged from $3.80-$ $4.80 \%$. Moisture content was higher in $100 \%$ wheat flour chin-chin (F) and sample A (4.80\%) respectively. These value which were significantly $(\mathrm{p}<0.05)$ higher compared to other products. Wahab et al. (2018) reported moisture content of $3.18-3.54 \%$ for chin-chin from wheat and cissus populnea stem composite flours. The values were within the range reported to have no adverse effect on quality attribute of the product (Mepba et al., 2007, Adebayo-Oyetoro et al., 2017). The low moisture content exhibited by the chin-chin samples is an indication that the products will have shelf stability (Ezeama, 2007).

The ash content of the chin-chin ranged from $1.90-3.65 \%$. There was significant difference $(\mathrm{p}<0.05)$ in ash content of the chin-chin samples. Combined effect of the various flour blends produced chin-chin with higher ash content compared with the control sample F (100\% wheat flour). Ndife et al. 
(2011) stated that ash content is a rough estimate of the mineral contents of foods.

Fat content of the chin-chin ranged from $12.60-16.70 \%$. Significantly $(\mathrm{p}<0.05)$ low fat value was recorded for $100 \%$ wheat chin-chin $(\mathrm{F})$. This corresponds with result from Table 1 , which revealed that wheat flour $(\mathrm{F})$ recorded lower oil absorption capacity compared with the blended flours. Increase in the fat content of the products may have resulted from frying. Higher fat content recorded for samples with high proportion of soybean is corroborated by Omoniyi et al. (2016) which stated that soybean is a high fat food. AdebayoOyetoro et al. (2017) reported higher fat values (21.05 $36.67 \%$ ) for chin-chin from wheat-tiger-nut flour blends, while Wahab et al. (2018) reported low fat content (6.33 $10.66 \%$ ) for chin-chin from wheat and Cissus populnea stem flour blends.

The fibre content of chin-chin snacks ranged from $2.10-$ $4.20 \%$. Higher fibre content was obtained in samples containing higher proportion (50\%) of OFSP than in the others. This is not surprising as OFSP is reported to have high fibre content (Akubor, 2004). There was significant difference in fibre content of the chin-chin. Foods with more fibre make an effective anti-constipation, lower cholesterol level in the blood and reduce the risk of various cancers (Wardlaw and Kessel, 2005). According to FAO/WHO, the recommended fibre contents of food products consumed should not exceed 5\%. Fibre content reported in this work is within safe limits.

Significantly $(\mathrm{p}<0.05)$ lower crude protein $(10.25 \%)$ was recorded in control sample $(\mathrm{F})$ compared with other products (Table 3). Chin-chin from flour blends containing higher soybean, sample D (19.38\%) and C (18.80\%), recorded higher protein values. Omoniyi et al. (2016) stated that soybean (a legume) is rich in protein. Wahab et al. (2018) reported lower protein $(5.22-12.98 \%)$ for chin-chin from wheat and Cissus populnea stem flour blends, AdebayoOyetoro et al. (2017) also reported lower protein values (7.66 - $11.58 \%$ ) for wheat-tiger-nut chin-chin, which is an indication that composite flour from maize, soybean and OFSP will be superior in providing protein when consumed. The carbohydrate content of the chin-chin ranged of $52.28-$ $65.10 \%$. Samples with higher proportion (50\%) of OFSP had higher values than other composite flours. However, the control flour $(\mathrm{F})$ had significantly higher $(\mathrm{p}<0.05)$ value compared to other composite flours. Carbohydrate content of the products is within the range of $52.95-62.76$ reported by Adebayo-Oyetoro et al. (2017) for chin-chin from wheattiger-nut flour blends. The high carbohydrate values showed that all samples can serve as energy rich sources.

Table 3: Proximate Composition of Chin-chin Samples (\%)

\begin{tabular}{lccccrc}
\multicolumn{1}{c}{ Samples } & Moisture & Ash & Fat & Fibre & Protein & Carbohydrate \\
\hline A & $4.80^{\mathrm{a}} \pm 0.14$ & $2.60^{\mathrm{d}} \pm 0.14$ & $14.70^{\mathrm{c}} \pm 0.14$ & $2.60^{\mathrm{b}} \pm 0.14$ & $14.75^{\mathrm{d}} \pm 0.00$ & $61.05^{\mathrm{b}} \pm 0.14$ \\
B & $4.70^{\mathrm{a}} \pm 0.14$ & $2.25^{\mathrm{e}} \pm 0.07$ & $12.60^{\mathrm{e}} \pm 0.00$ & $4.20^{\mathrm{a}} \pm 0.28$ & $11.73^{\mathrm{e}} \pm 0.00$ & $64.53^{\mathrm{a}} \pm 0.21$ \\
C & $3.80^{\mathrm{c}} \pm 0.00$ & $3.20^{\mathrm{b}} \pm 0.00$ & $16.35^{\mathrm{a}} \pm 0.21$ & $3.20^{\mathrm{b}} \pm 0.28$ & $18.80^{\mathrm{b}} \pm 0.00$ & $54.65^{\mathrm{d} \pm 0.49}$ \\
D & $4.40^{\mathrm{b}} \pm 0.14$ & $3.00^{\mathrm{c}} \pm 0.00$ & $15.80^{\mathrm{b}} \pm 0.14$ & $4.05^{\mathrm{a}} \pm 0.07$ & $15.28^{\mathrm{c}} \pm 0.18$ & $57.48^{\mathrm{c} \pm 0.18}$ \\
E & $4.20^{\mathrm{b}} \pm 0.00$ & $3.65^{\mathrm{a}} \pm 0.07$ & $16.70^{\mathrm{a}} \pm 0.14$ & $3.80^{\mathrm{a}} \pm 0.14$ & $19.38^{\mathrm{a}} \pm 0.18$ & $52.28^{\mathrm{e} \pm 0.18}$ \\
F & $4.80^{\mathrm{a}} \pm 0.28$ & $1.90^{\mathrm{f}} \pm 0.14$ & $13.85^{\mathrm{d}} \pm 0.78$ & $2.10^{\mathrm{d}} \pm 0.14$ & $10.25^{\mathrm{f}} \pm 0.00$ & $65.10^{\mathrm{a}} \pm 0.49$
\end{tabular}

Values are mean \pm SD. Values on the same column with different superscript are significantly different $(\mathrm{p}<0.05)$. Sample AMaize 50\%: Soybean 25\%: OFSP 25\%; B- Maize 25\%: Soybean 25\%: OFSP 50\%; C- Maize 25\%: Soybean 50\%: OFSP 25\%; D- Maize 0\%: Soybean 50\%: OFSP 50\%; E- Maize 50\%: Soybean 50\%: OFSP 0\%; F- 100\% wheat flour (Control)

\section{Mineral composition of chin-chin snaks}

The mineral composition of chin-chin snacks is presented in Table 4.

The result shows that the calcium content of the chin-chin ranged from $122.75 \mathrm{mg} / 100 \mathrm{~g}$ to $286.15 \mathrm{mg} / 100 \mathrm{~g}$. There was significant difference $(p<0.05)$ in the calcium content of the chin-chin samples. Higher calcium was observed in chin-chin containing higher levels of maize and soybean. Fasogbon et al. (2017) reported calcium content of 738.60-1262.60 mg/kg for chin-chin produced with wheat enriched with underutilized vegetables. Atobatele and Afolabi (2016) also reported improved calcium for soy-maize fortified cookies. Calcium is necessary for supporting bone formation and growth.

The magnesium content of the chin-chin samples was significantly different $(\mathrm{p}<0.05)$ and ranged from 88.62 $\mathrm{mg} / 100 \mathrm{~g}$ (control) - $178.05 \mathrm{mg} / 100 \mathrm{~g}$ (Sample A). The higher values obtained for composite flour chin-chin samples compared with the control (F) showed that combining maize, soybean and OFSP flour enhanced the magnesium content of the snakst. Value obtained in this study was higher than the range of $5.60-13.60 \mathrm{mg} / 100 \mathrm{~g}$ reported for maize-wheat chinchin (Ojinnaka et al., 2016). Olubukola et al. (2017) reported a comparable range of $92.32-176.23 \mathrm{mg} / 100 \mathrm{~g}$ for chin-chin made from wheat flour enriched with pumpkin and spinach vegetables. Magnesium is essential to good health because it helps to maintain normal muscle and nerve function, keeps heart rhythm steady, supports a healthy immune system and keeps bones strong.

The sodium, potassium and phosphorus content of the samples range from $12.13-46.35,195.95-412.59$, and 78.23 $-139.17 \mathrm{mg} / 100 \mathrm{~g}$ respectively. The control sample had lower values compared to composite flour samples. Sample B had the highest sodium content (46.35\%), sample $\mathrm{C}$ had the highest potassium content $412.59 \%$, while sample $\mathrm{A}$ had the highest phosphorus content (139.17\%). Higher potassium 
content $(261.30$ - $425.89 \mathrm{mg} / 100 \mathrm{~g})$ was reported by Olubukola et al. (2017) for chin-chin made from wheat flour enriched with pumpkin and spinach vegetables. This could be due the fact that vegetable are known to have high potassium content (Hossain et al., 2014). Igbabul et al. (2014) reported a lower phosphorus content of $50-70 \mathrm{mg} / 100 \mathrm{~g}$ for bread made from wheat, maize and OFSP flour. Chin-chin rich in these nutrients would enhance the health of both children and adults when consumed (Igbabul et al., 2014).

Table 4: Mineral Composition of Chin-chin Samples (mg/100kg)

\begin{tabular}{llllll}
\hline Samples & Calcium & Magnesium & Sodium & Potassium & Phosphorus \\
\hline A & $286.15^{\mathrm{a}} \pm 0.00$ & $178.05^{\mathrm{a}} \pm 0.85$ & $28.05^{\mathrm{e}} \pm 0.69$ & $234.43^{\mathrm{c}} \pm 0.07$ & $139.17^{\mathrm{a}} \pm 0.57$ \\
B & $193.79^{\mathrm{e}} \pm 0.79$ & $143.11^{\mathrm{e}} \pm 0.30$ & $46.35^{\mathrm{a}} \pm 0.00$ & $329.22^{\mathrm{d}} \pm 0.45$ & $97.19^{\mathrm{e}} \pm 1.18$ \\
C & $218.93^{\mathrm{c}} \pm 0.55$ & $154.35^{\mathrm{c}} \pm 0.00$ & $33.66^{\mathrm{d}} \pm 0.79$ & $412.59^{\mathrm{a}} \pm 0.00$ & $112.32^{\mathrm{c}} \pm 0.00$ \\
D & $206.38^{\mathrm{d}} \pm 0.00$ & $148.89^{\mathrm{d}} \pm 0.32$ & $38.99^{\mathrm{b}} \pm 0.29$ & $366.39^{\mathrm{b}} \pm 12.73$ & $103.87^{\mathrm{d} \pm 0.86}$ \\
E & $243.41^{\mathrm{b}} \pm 0.58$ & $162.92^{\mathrm{b}} \pm 0.38$ & $35.22^{\mathrm{c}} \pm 0.00$ & $292.25^{\mathrm{e}} \pm 1.13$ & $121.99^{\mathrm{b}} \pm 0.84$ \\
F & $122.75^{\mathrm{f}} \pm 0.92$ & $88.62^{\mathrm{f}} \pm 0.06$ & $12.13^{\mathrm{f}} \pm 0.74$ & $195.95^{\mathrm{f}} \pm 0.57$ & $78.23^{\mathrm{f}} \pm 0.00$
\end{tabular}

Values are mean \pm SD. Values on the same column with different superscript are significantly different ( $<<0.05)$. Sample AMaize 50\%: Soybean 25\%: OFSP 25\%; B- Maize 25\%: Soybean 25\%: OFSP 50\%; C- Maize 25\%: Soybean 50\%: OFSP 25\%; D- Maize 0\%: Soybean 50\%: OFSP 50\%; E- Maize 50\%: Soybean 50\%: OFSP 0\%; F- 100\% wheat flour (Control)

\section{Vitamin composition from of chin-chin snacks}

Table 5 shows the vitamin $\mathrm{B}_{1}$ content of the chin-chin samples to range from 0.021 to $0.135 \mathrm{mg} / 100 \mathrm{~g}$. There was significant difference $(p<0.05)$ in thiamine content of the chin-chin sacks. The trend of the values showed that OFSP improved the $\mathrm{B}_{1}$ content of the samples. This supports the report of Temesgen (2015) that OFSP is high in vitamin $\mathrm{B}_{1}$. The entire composite flour chin-chin snacks had higher values (0.041 $0.135 \mathrm{mg} / 100 \mathrm{~g})$ than the control $\mathrm{F}(0.021 \mathrm{mg} / 100 \mathrm{~g})$. This suggests that blending maize, soybean and OFSP flour resulted in snacks with higher vitamin $\mathrm{B}_{1}$ than using wheat flour only (control).

Vitamin $\mathrm{B}_{2}$ content ranged 0.038 to $0.086 \mathrm{mg} / 100 \mathrm{~g}$. Vitamin $\mathrm{B}_{2}$ of the snacks were more enhanced by OFSP, followed by soybean as shown in the result. This is in accordance with the submission of Igbabul et al. (2014) who reported that OFSP has higher $\mathrm{B}_{2}$ vitamin than maize. The report suggests that addition of higher level of OFSP in flour blends enhanced their vitamin $\mathrm{B}_{2}$ content of the snacks.

Vitamin $B_{3}$ and beta carotene content of the chin-chin samples ranged from $0.41-1.31 \mathrm{mg} / 10 \mathrm{~g}$ and $3.13-215.8 \mu \mathrm{g} / \mathrm{g}$ respectively. There were significant differences $(\mathrm{p}<0.05)$ in the niacin and beta carotene contents of the chin-chin samples. Chin-chin snacks containing higher quantity of OFSP had higher values in beta carotene. Sample B had the highest value in beta carotene $(215.18 \mu \mathrm{g} / \mathrm{g})$ followed by sample D (202.03 $\mu \mathrm{g} / \mathrm{g})$ and sample A (65.26 $\mu \mathrm{g} / \mathrm{g})$ respectively. The trend obtained in this is in line with the report of Igbabul et al. (2014) and Temesgen (2015) that OFSP contains high amount of vitamins, especially, beta carotene. Vitamins are required for the proper functioning of the body fluid systems (Tadesse et al., 2015).

Table 5: Vitamin Composition of the Chin-chin Samples

\begin{tabular}{lllll}
\hline Samples & $\mathrm{B}_{1}(\mathrm{mg} / 100 \mathrm{~g})$ & $\mathrm{B}_{2}(\mathrm{mg} / 100 \mathrm{~g})$ & $\mathrm{B}_{3}(\mathrm{mg} / 100 \mathrm{~g})$ & Beta-carotene $(\mu \mathrm{g} / \mathrm{g})$ \\
\hline $\mathrm{A}$ & $0.083^{\mathrm{b}} \pm 0.02$ & $0.045^{\mathrm{d}} \pm 0.69$ & $0.77^{\mathrm{b}} \pm 0.03$ & $65.26^{\mathrm{c}} \pm 0.55$ \\
$\mathrm{~B}$ & $0.135^{\mathrm{a}} \pm 0.04$ & $0.086^{\mathrm{a}} \pm 0.00$ & $1.31^{\mathrm{a}} \pm 0.04$ & $215.18^{\mathrm{a}} \pm .122$ \\
$\mathrm{C}$ & $0.041^{\mathrm{d}} \pm 0.02$ & $0.05^{6} \pm 0.00$ & $0.58^{\mathrm{c}} \pm 0.03$ & $53.53^{\mathrm{d}} \pm 0.48$ \\
$\mathrm{D}$ & $0.065^{\mathrm{c}} \pm 0.03$ & $0.070^{\mathrm{b}} \pm 0.02$ & $0.73^{\mathrm{b}} \pm 0.00$ & $202.03^{\mathrm{b}} \pm 0.65$ \\
$\mathrm{E}$ & $0.071^{\mathrm{c}} \pm 0.04$ & $0.053^{\mathrm{c}} \pm 0.01$ & $0.75^{\mathrm{b}} \pm 0.01$ & $8.43^{\mathrm{e}} \pm 0.00$ \\
$\mathrm{~F}$ & $0.021^{\mathrm{e}} \pm 0.03$ & $0.038^{\mathrm{e}} \pm 0.03$ & $0.41^{\mathrm{d}} \pm 0.03$ & $3.13^{\mathrm{f}} \pm 0.04$ \\
\hline
\end{tabular}

Values are mean \pm SD. Values on the same column with different superscript are significantly different $(\mathrm{p}<0.05)$ Sample: A- Maize 50\%: Soybean 25\%: OFSP 25\%; B- Maize 25\%: Soybean 25\%: OFSP 50\%; C- Maize 25\%: Soybean 50\%: OFSP 25\%; D- Maize 0\%: Soybean 50\%: OFSP 50\%; E- Maize 50\%: Soybean 50\%: OFSP 0\%; F- 100\% wheat flour (Control)

\section{Phytochemical composition of chin-chin snacks}

Table 7 presents the result of the phytochemical composition of chin-chin samples.

The highest tannin $(1.75-2.78 \mathrm{mg} / 100 \mathrm{~g})$, phytate $(1.80-2.60$ $\mathrm{mg} / 100 \mathrm{~g})$ and flavonoid $(1.20-1.80 \mathrm{mg} / 100 \mathrm{~g})$ contents were found in samples C and D which contained the highest quantity of soybean. This supports the report of Fasoyiro et al. (2006) that legumes are high in anti-nutrients. Higher oxalate $(5.34 \mathrm{mg} / 100 \mathrm{~g})$ and $\mathrm{HCN}(0.78 \mathrm{mg} / 100 \mathrm{~g})$ contents were obtained in sample B. Habtamu (2014) reported high $\mathrm{HCN}(4.23-823 \mathrm{mg} / 10 \mathrm{~g})$ and oxalate $(8.16-12.67 \mathrm{mg} / 100 \mathrm{~g})$ content for Artichoke tubers. Tewodros et al. (2018) also reported high value $\mathrm{HCN}$ for different yam species in Ethiopia. The control (F) had lower tannin $(0.42 \mathrm{mg} / 100 \mathrm{~g})$, phytate $(0.19 \mathrm{mg} / 100 \mathrm{~g})$, oxalate and $\mathrm{HCN}(0.08 \mathrm{mg} / 100 \mathrm{~g})$ contents compared to the composite chin-chin samples. Tannin compounds have some antibacterial effects (Akinyma et al., 2001), antiviral and anti-parasitic effects in human body 
(Wardlaw and Kessel, 2005). Flavonoid is a potent antioxidant and free radical scavenger and guard cell membranes from damage (Noda et al., 2000). Excessive ingestion of antinutritional compounds like phytate, oxalate and cyanogenic glycosides can be lethal to human health (Alector, 1995; Akinyma et al., 2001). However, values obtained in this work were very low and therefore safe for human consumption.

Table 6: Phytochemical Composition of the Chin-chin Samples (mg/100g)

\begin{tabular}{|c|c|c|c|c|c|}
\hline Samples & Tannin & Phytate & Oxalate & Flavonoid & $\mathrm{HCN}$ \\
\hline A & $0.85^{\mathrm{e}} \pm 0.00$ & $0.32^{\mathrm{d}} \pm 0.00$ & $1.40^{\mathrm{e}} \pm 0.07$ & $0.25^{\mathrm{e}} \pm 0.03$ & $0.21^{\mathrm{c}} \pm 0.00$ \\
\hline B & $1.31^{\mathrm{d}} \pm 0.02$ & $0.19^{\mathrm{e}} \pm 0.00$ & $5.34^{\mathrm{a}} \pm 0.08$ & $2.70^{\mathrm{a}} \pm 0.00$ & $0.76^{\mathrm{a}} \pm 0.08$ \\
\hline $\mathrm{C}$ & $2.78^{\mathrm{a}} \pm 0.00$ & $2.60^{\mathrm{a}} \pm 0.07$ & $3.59^{c} \pm 0.19$ & $1.20^{\mathrm{c}} \pm 0.14$ & $0.31^{\mathrm{c}} \pm 0.00$ \\
\hline D & $1.75^{\mathrm{b}} \pm 0.03$ & $1.80^{\mathrm{b}} \pm 0.21$ & $4.27^{\mathrm{b}} \pm 0.00$ & $1.80^{\mathrm{b}} \pm 0.21$ & $0.50^{\mathrm{b}} \pm 0.14$ \\
\hline $\mathrm{E}$ & $1.54^{\mathrm{c}} \pm 0.00$ & $1.25^{\mathrm{c}} \pm 0.00$ & $2.65^{\mathrm{d}} \pm 0.00$ & $0.90^{\mathrm{d}} \pm 0.00$ & $0.63^{\mathrm{ab}} \pm 0.00$ \\
\hline $\mathrm{F}$ & $0.42^{\mathrm{f}} \pm 0.00$ & $0.19^{\mathrm{e}} \pm 0.00$ & $0.82^{\mathrm{f}} \pm 0.06$ & $0.65^{\mathrm{d}} \pm 0.00$ & $0.08^{\mathrm{d}} \pm 0.01$ \\
\hline
\end{tabular}

Values are mean \pm SD. Values on the same column with different superscript are significantly different $(\mathrm{p}<0.05)$. Sample AMaize 50\%: Soybean 25\%: OFSP 25\%; B- Maize 25\%: Soybean 25\%: OFSP 50\%; C- Maize 25\%: Soybean 50\%: OFSP 25\%; D- Maize 0\%: Soybean 50\%: OFSP 50\%; E- Maize 50\%: Soybean 50\%: OFSP 0\%; F- 100\% wheat flour (Control)

\section{Sensory evaluation of chin-chin snacks}

Table 7 shows the result of the sensory evaluation of chinchin samples.

The control (F) from 100\% wheat flour, had higher score in all the sensory parameters evaluated compared to the composite chin-chin snacks. Sample D was the least preferred in all the parameters. Sample A (6.80) and E (6.20) with 50\% maize had the highest scores for crispiness among the composite chin-chin snacks. Taste scores were low in composite chin-chin samples of C (4.60) and D (4.20) with high soybean levels. Soybean was reported by Ndife et al. (2011) to impose beany taste and flavour on food products, especially when incorporated at a high level. The high inclusion of OFSP (50\%) in sample B (5.50) and D (4.40) resulted in their low colour scores. The panellists were not familiar with the reddish colour imparted by OSFP flour to these chin-chin. Sample A with a flour mix of maize 50\%, soybean $25 \%$, OFSP $25 \%$ was most preferred composite chinchin. Overall, the control chin-chin was the most acceptable (7.30), other composite chin-chin also had favourable responses (5.20 - 6.70), except for sample D (4.62). General/overall acceptability is the combination of all the other sensory attributes (Iwe et al., 2017).

Table 7: Sensory Evaluation of Chin-Chin Samples

\begin{tabular}{llllll}
\hline Samples & Taste & Colour & Aroma & Crispiness & General Acceptability \\
\hline A & $6.60^{\mathrm{b}} \pm 0.68$ & $6.40^{\mathrm{b}} \pm 0.30$ & $7.00^{\mathrm{ab}} \pm 0.79$ & $6.80^{\mathrm{ab}} \pm 1.01$ & $6.70^{\mathrm{ab}} \pm 0.80$ \\
B & $6.20^{\mathrm{b}} \pm 1.11$ & $5.50^{\mathrm{c}} \pm 1.05$ & $6.20^{\mathrm{bc}} \pm 1.11$ & $6.00^{\mathrm{b}} \pm 1.12$ & $6.00^{\mathrm{bc}} \pm 1.12$ \\
C & $4.60^{\mathrm{c}} \pm 1.23$ & $5.80^{\mathrm{bc}} \pm 1.01$ & $5.60^{\mathrm{cd}} \pm 1.73$ & $5.00^{\mathrm{c}} \pm 1.23$ & $5.20^{\mathrm{cd}} \pm 1.70$ \\
D & $4.20^{\mathrm{c}} \pm 1.77$ & $4.40^{\mathrm{d}} \pm 1.60$ & $4.80^{\mathrm{d}} \pm 1.64$ & $4.60^{\mathrm{c}} \pm 1.84$ & $4.62^{\mathrm{d}} \pm 1.67$ \\
E & $5.00^{\mathrm{c}} \pm 1.38$ & $6.20^{\mathrm{bc}} \pm 1.20$ & $6.60^{\mathrm{b}} \pm 0.94$ & $6.20^{\mathrm{b}} \pm 1.20$ & $5.60^{\mathrm{c}} \pm 1.05$ \\
F & $7.40^{\mathrm{a}} \pm 1.14$ & $7.20^{\mathrm{a}} \pm 1.20$ & $7.50^{\mathrm{a}} \pm 1.24$ & $7.40^{\mathrm{a}} \pm 1.14$ & $7.30^{\mathrm{a}} \pm 1.03$
\end{tabular}

Values are mean \pm SD. Values on the same column with different superscript are significantly different $(\mathrm{p}<0.05)$

Sample A- Maize 50\%: Soybean 25\%: OFSP 25\%; B- Maize 25\%: Soybean 25\%: OFSP 50\%; C- Maize 25\%: Soybean 50\%: OFSP 25\%; D- Maize 0\%: Soybean 50\%: OFSP 50\%; E- Maize 50\%: Soybean 50\%: OFSP 0\%; F- 100\% wheat flour (Control)

\section{CONCLUSION}

High nutrient dense chin-chin snacks were produced from flour blends of maize, soybean and orange-flesh sweet potato. The result obtained showed that the composite flour mixture of maize, soybean and OFSP resulted in improved quality flour with better functional properties. More so the chin-chin snacks had better nutrient quality indexes (proximate, mineral and vitamin compositions) compared to the $100 \%$ wheat flour chin-chin. Anti-nutrient compositions of the chin-chin were within safe limits for human consumption. The sensory evaluation showed that the panellists had higher preference for chin-chin made from $100 \%$ wheat flour, followed by the chin-chin made from $50 \%$ maize, $25 \%$ soybean and $25 \%$ OFSP (sample A). Therefore, the use of maize-soybeanOFSP blends in composite flour technology to reduce over dependency on wheat as sole flour for pastries and confectionaries and for improved nutritious snacks is recommended.

\section{REFERENCES}

A.O.A.C. (2010). Official Methods of Analysis of the Association of Official Analytical Chemists, $18^{\text {th }}$ edition. Gaithersburg, Maryland, U.S.A.

Adebayo-Oyetoro, A. O., Ogundipe, O. O., Lofinmakin, K. F., Akinwande, F. F., Aina, D. O. and Adeyeye, S. A. O. (2017). Production and acceptability of chin-chin snack made from wheat and tigernut (Cyperus esculentus) flour. Cogent Food and Agriculture, 3: 1-9. 
Akubor, P. I. (2004). Protein Contents, Physical and Sensory Properties of Nigerian Snack Foods (Cake, Chin-Chin and Puff-Puff) Prepared from Cowpea - Wheat Flour Blends, International Journal of Food Science and Technology, 9: 419-424.

Atobatele, O. B. and Afolabi, M. O. (2016). Chemical composition and sensory evaluation of cookies baked from the blends from the blends of soya bean and maize flours. Applied Tropical Agriculture, 21(2): 8-13

Awoyale, W., Maziya-Dixon, B., Sanni, L. O. and Shittu, T. A. (2011). Nutritional and sensory properties of a maizebased snack food (kokoro) supplemented with treated distillers' spent grain (DSG). International Journal of Food Science and Technology, 46(8): 1609-1620.

Baafi, E., Manu-Aduening, J., Carey, E. E., Ofori, K., Blay, E. T. and Gracen, V. E. (2015). Constraints and breeding priorities for increased sweet potato utilization in Ghana. Sustainable Agriculture Research, 4(4), 1-16.

Bibiana, I., Grace, N. and Julius, A. (2014). Quality evaluation of composite bread produced from wheat, maize and orange fleshed sweet potato flours. American Journal of Food Science and Technology, 2(4): 109-115.

Enwere, N. J. (1998). Foods of Plant Origin. Afro-Orbis Publications Limited, Nsukka, Nigeria.

Ezeama, C. F. (2007). Food Microbiology: Fundamentals and Applications. Natural Prints Ltd, Lagos, Nigeria, Pp. 34.

Fasogbon, B. M., Taiwo, K. A. and Oyedele, D. J. 2017. Nutritional assessment and consumer acceptability of snacks (chin-chin and cookies) enriched with underutilized indigenous vegetables. International Journal of Food and Nutritional Science, 6(3): 97-108.

Fasoyiro, S. B., Ajibade, S. R., Omole, A. J., Adeniyan, O. N. and Farinde, E. O. (2006). Proximate, minerals and antinutritional factors of some under-utilized grain legumes in the south-west Nigeria. Journal of Nutrition and Food Science, 36:18-23.

Habtamu, F. (2014). Nutritional composition, antinutritional factors and effect of boiling on nutritional composition of Anchote (Coccinia Abyssinica) tubers. Food Science and Quality Management, 26:1-43

Hossain, N., Islam M., Alamgir, M. and Kibria, M. G. (2014). Growth response of Indian spinach to biogas plant residues IOSR. Journal of Pharmacy and Biological Science, 9(2): 0106.

Hotz, C., Loechl, C., Brauw, A., De-Eozenou, P., Gilligan, D., Moursi, M. and Meenakshi, J. V. (2012). A large-scale intervention to introduce orange sweet potato in rural
Mozambique increases vitamin A intakes among children and women. British Journal of Nutrition, 108(1): 163-176.

Igbabul, B., Num, G. and Amove, J. (2014). Quality evaluation of composite bread produced from wheat, maize and orange fleshed sweet potato flours. American Journal of Food Science and Technology, 2(4): 109-115.

Iwe, M. O. (2010). Handbook of Sensory Methods and Analysis. $2^{\text {nd }}$ Edition. Rojoint Communication Services Ltd, Enugu, Nigeria.

Iwe, M. O., Linus-Chibuezeh, A., Ngadi, M., Asumugha, V. U. and Obasi, N. E. (2017). Bread from cassava-wheat flours: Effect of cassava variety, flour composite and improves on the physical and sensory properties of bread loaves. Imperial Journal of Interdisciplinary Research, 3(9): 651-664.

Lasekan, O. O. and Akintola, A. M. (2002). Production and nutritional evaluation of puffed soy maize snacks. Journal of Cereal Science, 24:79-85.

Linus-Chibuezeh, A., Iwe, M. O., Ngadi, M., Asumugha, V. U. and Obasi, N. E. (2017). Evaluation of some physicochemical and pasting properties of three improved cassava varieties available in the southeast of Nigeria. Imperial Journal of Interdisciplinary Research, 3(9): 641-650

Mepba, H. D., Eboh, L. and Banigo E. B. (2007). Effect of processing treatments on the nutritive composition and consumer acceptance of some Nigerian edible leafy vegetables. African Journal of Food Agriculture Nutrition and Development, 7(1):23-26.

Mohammed, I., Ahmed, A. R. and Senge, B. (2012). Dough rheology and bread quality of wheat chickpea flour blends. Industrial Crops and Products, 36: 196-202.

Ndife J., Abdulraheem, L. O. and Zakari, U. M. (2011). Evaluation of the nutritional and sensory quality of functional breads produced from whole wheat and soya bean flour blends. African Journal of Food Science, 5(8): 466-472.

Noda, Y., Kneyuki, T., Mori, A. and Packer, L. (2000). Antioxidant activity of nasunin, an anthocyanin in eggplant. Toxicology, 148(2-3): 119-123.

Ojinaka, M. C., Emeh, T. C. and Okorie, S. U. (2016). Evaluation of the quality of composite maize-wheat chinchin enriched with Rhynchophorous phoenicis. Journal of Food Research, 5(4): 19-27.

Okoye, J. I., Nkwocha, A. C. and Ogbonnaya, A. E. (2008). Production, proximate composition and consumer acceptability of biscuits from wheat-soybean flour blends. Continental Journal of Food Science and Technology, 2: 613.

Olubukola, A., Olasunkanmi, G., Kehinde, T., Durodoluwa, J. Oyedele and Adebooye, C. (2017). Proximate, mineral, 
sensory evaluations and shelf stability of chinchin enriched with ugu and Indian spinach vegetables. International Journal of Biochemistry Research and Review, 18(4): 1-14.

Omoniyi, S. A., Awonorin, S. O., Idowu, M. A. and Adeola, A. A. (2016). Physico-chemical and functional properties of sweet potato-soybean flour blends. Applied Tropical Agriculture, 21 (2): 84-88.

Onwuka G. I. (2018). Food Analysis and Instrumentation. Theory and Practice. Naphthali Prints, Lagos, Nigeria.

Oyeyinka, S. A., Oyeyinka, A. T. Olayinka, K. R., Karim, O. R., Toyeeh, K. A., Olatunde, S. J. and Arise, A. K. (2014). Biscuit making potentials of flours from wheat and plantain at different stages of ripeness. Croatian Journal of Food Science and Technology, 8(1): 36-42.

Pearson, D. (1976). The Chemical Analysis of Foods. 7th ed. Churchill Livingstone, Edinburg, U.K.

Singh, S., Riar, C. S. and Saxena, D. C. (2008). Effect of incorporating sweet potato flour to wheat flour on the quality characteristics of cookies. African Journal of Food Science, 2: $65-72$.

Tadesse, T. F., Nigusse, G. Kurabachew, H. (2015). Nutritional, microbial and sensory properties of flat-bread (kitta) prepared from blends of maize (Zea mays L.) and orange-fleshed sweet potato (Ipomoea batatas L.) flours. International Journal of Food Science and Nutrition Engineering, 5(1): 33-39.

Temesgen L., Abebe, H. and Fekadu, T. (2015). Production and quality evaluation of cookies enriched with $\beta$-carotene by blending orange-fleshed sweet potato and wheat flours for alleviation of nutritional insecurity. International Journal of Food Science and Nutritional Engineering, 5(5): 209-217.
Tewodros, M., Mesfin, S., Getachew, W., Ashenafi, A., and Neim, S. (2018). Effect of inorganic $\mathrm{N}$ and $\mathrm{P}$ fertilizer on the fruit yield and yield components of pineapple (Annanas comosus, Var. smooth cayenne) at Jimma, Southwest Ethiopia. Agrotechnology, 7(1):179.

Tumwegamire, S., Kapinga, R., Zhang, D., Crissman, C. and Agili, S. (2004). Opportunities for promoting orange-fleshed sweet potato as a mechanism for combat vitamin-A deficiency in sub-saharan Africa. African Crop Science Journal, 12(3), 241-252.

Ugwuanyi, R. G., Eze, J. I. and Okoye, E. C. (2020). Effect of soybean, sorghum and african breadfruit flours on the proximate composition and sensory properties of chin-chin. European Journal of Nutrition and Food Safety, 12(1): 85-98.

Wahab, N. O., Akano, R. A., Kareem, S. O. and Maxwell, Y. M. (2018). Quality evaluation of chin-chin produced from a blend of wheat flour and underutilized edible plant: Cissus populnea flour. Nigerian Journal of Nutritional Sciences, 39(2): 1-9.

Wan, J. C. and Kinsella, J. E. (1991). Comparative studies on functional properties of whole and dehulled cowpea seed flour (Vigna unguiculata). Pakistan Journal of Nutrition, 10(9): 899-902.

Wardlaw, G. M. and Kessel, M. (2005). Perspectives in Nutrition. $7^{\text {th }}$ ed. McGraw Hill Publisher, New York, U.S.A.

C 2020 This is an Open Access article distributed under the terms of the Creative Commons Attribution 4.0 International license viewed via https://creativecommons.org/licenses/by/4.0/ which permits unrestricted use, distribution, and reproduction in any medium, provided the original work is cited appropriately. 